\title{
Pengaruh Model Pembelajaran Kooperatif Tipe Two Stay Two Stray terhadap Hasil Belajar Siswa pada Pembelajaran Tematik di Kelas V SDN Gugus XIX Kota Bengkulu
}

\section{Tiya Anjani}

Universitas Bengkulu

Tiyaanjani12@gmail.com

\section{Nani Yuliantini}

Universitas Bengkulu

\author{
Abdul Muktadir \\ Universitas Bengkulu
}

\begin{abstract}
The study aimed to determine the effect of Two Stay Two Stray cooperative learning model on student learning outcomes in Thematic learning in $V$ class SDN Gugus XIX of Bengkulu City. This research was quantitative research. The research method was quasi-experimental with the type of design matching onle pretest-posttest control group design. The population of this study were five grade in Gugus XIX of the city of Bengkulu City. The sample in this study were VC class SDN 71 Bengkulu City and V class SDN 103 Bengkulu City. The sampling technique used cluster random sampling. The research instruments was a knowledge learning result is multiple choice questions (pretest and posttest). For the attitude and skills aspects used is observation sheets. The data analysis by using descriptive statistics and inferential statistic. The results shows that the t-test score obtains in the Indonesian language is 4.012 and in the natural science is 2,941 with ttables at the 5\% significance level of, 1,669 where t-count is greater than $t$ table. It can be concluded, that there is a significant effect on student learning outcomes in Thematic learning using the type Two Stay Two Stray cooperative leaning model.
\end{abstract}

Keywords: Cooperative Learning Model Type Two Stay Two Stray, Thematic, Learning Outcomes

\section{Pendahuluan}

Pembelajaran Tematik merupakan pendekatan pembelajaran yang menggunakan tema-tema dalam mengintegrasikan muatan mata pelajaran yang ada. Tema-tema tersebut digunakan sebagai gagasan utama yang menjadi pokok 
perbincangan ketika proses pembelajaran berlangsung. Sehingga, pengetahuan yang diserap oleh siswa tidak terpisah-pisah atau bersifat utuh. Maka dari itu, pembelajaran Tematik dapat memberikan pembelajaran yang bermakna bagi siswa sehingga terciptanya interaksi yang tepat dan dekat antara guru dan siswa (Widyaningrum, 2012: 119 ; Hidayah, 2015: 48).

Pada penerapan pembelajaran Tematik di sekolah dasar, siswa mendapatkan pengalaman langsung dalam mengaitkan pengetahuan yang satu dengan pengetahuan yang lainnya. Proses pembelajaran yang memberikan pengalaman langsung ini, siswa akan disuguhkan pada sesuatu yang bersifat nyata (konkret) sebagai pondasi agar lebih mudah dalam memahami hal-hal yang tidak nyata (abstrak). Hal tersebut sesuai dengan karakteristik anak sekolah dasar yang berada pada tahapan operasional konkret (Concrete Operations). Pada usia ini (7-11 tahun) yaitu usia anak sekolah dasar, anak mulai berpikir pada obyek-obyek atau peristiwaperistiwa yang nyata atau konkret (Piaget dalam Sit, 2017: 140).

Pembelajaran Tematik harus dirancang agar hasil belajar yang didapat akan maksimal. Oleh karena itu, guru tentunya harus memiliki kemampuan dalam menciptakan interaksi yang baik agar suasana kelas menjadi lebih aktif dengan aktivitas pembelajaran. Hal tersebut dipertegas oleh Susanto (2016: 18) yang menyatakan bahwa yang memegang kunci sukses sebagai penentu keberhasilan proses pembelajaran Tematik akan banyak dipengaruhi oleh kemampuan guru yaitu guru yang profesional. Guru yang profesional merupakan guru yang memiliki kompetensi dalam bidangnya seperti menguasai materi pembelajaran yang akan diajarkan dan mampu memilih metode pembelajaran yang tepat sehingga pendekatan pembelajaran Tematik ini bisa berjalan dengan semestinya.

Namun pada pelaksanaannya di lapangan, proses pembelajaran Tematik masih ditemukan guru yang menggunakan model pembelajaran yang bersifat konvensional. Pada model pembelajaran ini, guru hanya mentransfer pengetahuan kepada seluruh siswa tanpa ada kegiatan lainnya dan siswa lebih bersifat sebagai penerima. Siswa hanya menerima segala hal baik itu informasi, materi, dan nasihat yang akan diberikan oleh seorang guru tanpa ada kegiatan berpikir kritis lainnya seperti memecahkan masalah dalam diskusi kelompok. Dengan kata lain, model pembelajaran ini masih berpusat pada guru. Padahal salah satu karakteristik pembelajaran Tematik yaitu pembelajaran yang berpusat pada kegiatan siswa bukan hanya pada guru. Hal tersebut dijelaskan oleh Ula (2013: 116) bahwa model pembelajaran konvensional ini masih menjadi model pembelajaran yang paling banyak dan sering digunakan oleh guru sebagai alternatif dalam memudahkan guru mentransfer ilmu kepada siswa, di mana guru menempatkan siswa sebagai obyek yang diam, tanpa terlibat langsung dalam proses pembelajaran atau bisa disebut siswa yang pasif sehingga siswa hanya bisa menerima secara utuh dari guru. Tentu ini bukan upaya yang baik dalam mengimplementasikan makna dari pembelajaran Tematik.

Berdasarkan permasalahan tersebut agar hasil belajar yang didapat maksimal guru perlu merancang sebuah model pembelajaran yang berpusat pada keaktifan siswa. Salah satu yang dapat digunakan yaitu dengan diskusi kelompok atau biasa dikenal dengan model pembelajaran kooperatif. Mudiofir dan Rusydiyah (2016: 83) berpendapat bahwa di dalam pembelajaran kooperatif siswa berusaha untuk memperoleh pengalaman sikap kepemimpinan dalam dirinya dan mampu membuat keputusan dalam rangka keperluan untuk memecahkan masalah atau diskusi kelompok, siswa difasilitasi untuk belajar bersama-sama tanpa memperdulikan latar belakang dari anggota kelompoknya.

Penggunaan model kooperatif ini siswa akan bekerja sama dan berinteraksi antar teman kelompok maupun teman sekelas. Pengetahuan yang didapat oleh siswa 
tidak hanya dari guru namun juga dari teman sebayanya. Guru hanya memfasilitasi dan memberikan motivasi kepada siswa untuk membangun pengetahuan dan pemikirannya sendiri. Penggunaan model ini dapat memberikan siswa pengalaman langsung untuk menuangkan ide-ide serta pendapatnya kepada teman sebaya. Sehingga salah satu karakteristik pembelajaran Tematik dapat diwujudkan yaitu pembelajaran yang berpusat pada siswa.

Namun pada proses pembentukkan kelompoknya, guru membentuk kelompok secara permanen atau tidak adanya modifikasi dalam membagi anggota kelompok dengan alasan menghemat waktu dan siswa telah saling mengenal satu sama lain. Padahal pembentukkan kelompok seperti ini akan membuat siswa menjadi bosan, perselihan mungkin saja terjadi, interaksi dengan yang lain menjadi kurang (Lie, 2014: 46). Kekurangan ini bisa diatasi dengan menggunakan salah satu model pembelajaraan kooperatif tipe Two Stay Two Stray yang berarti Dua Tinggal Dua Tamu.

Menurut Shoimin (2014: 222) model pembelajaran kooperatif dua tinggal dua tamu adalah dua orang siswa tinggal atau bisa disebut tuan rumah bertugas menyajikan informasi kepada tamu mengenai hasil kerja kelompoknya, sedangkan yang bertugas sebagai tamu atau berkunjung bertugas mencari dan mencatat hasil diskusi kelompok yang dikunjunginya.

Adapun langkah-langkah pembelajaran dalam model pembelajaran tipe Two Stay Two Stray menurut Lestari dan Yudhanegara (2015: 51) yaitu kegiatan dimulai dengan presentasi kelas oleh guru di mana guru menyajikan materi secara langsung kepada siswa, pembentukan kelompok yang terdiri atas 4 orang siswa yang heterogen, siswa bekerja sama dalam kelompoknya untuk menyelesaikan masalah yang diberikan guru yaitu berupa lembar kerja. Dua orang siswa tetap tinggal di kelompoknya dan menyajikan hasil pekerjaan kelompoknya kepada siswa yang datang dari kelompok lain. Dua orang siswa lainnya bertamu ke kelompok lain untuk mencari berbagai informasi dan mencatat penjelasan dari kelompok lain yang disinggahi. Setelah mencatat penjelasan dari kelompok lain, dua orang yang bertamu tersebut, kemudian kembali kepada kelompoknya untuk berbagi informasi yang diperoleh kepada dua anggota lainnya yang tinggal di kelompoknya.

Peneliti memilih menggunakan model pembelajaran ini dikarenakan memiliki kelebihan dapat digunakan dalam semua mata pelajaran dan semua tingkat usia siswa. Model ini lebih berpusat pada keaktifan siswa untuk mencari informasi dengan cara berinteraksi dan bekerja sama dengan anggota kelompoknya, tetapi siswa juga dapat berinteraksi dan bekerja sama dengan kelompok lain sehingga terciptanya keakraban sesama teman dalam suatu kelas (Fathurrohman, 2015: 91).

Model pembelajaran kooperatif tipe Two Stay Two Stray telah terbukti dapat berpengaruh terhadap hasil belajar siswa. Hasil penelitian Fitrianingrum (2018: 953) yang menunjukkan adanya pengaruh model pembelajaran kooperatif tipe Two Stay Two Stray terhadap hasil belajar siswa pada materi sumber energi alternatif di kelas IV SDN di Gugus 01 Sidoarjo. Pengaruh tersebut dapat dibuktikan dari hasil penelitian yang diperoleh, yaitu; (1) pada perhitungan yang dilakukan diperoleh hasil $3.209<-2.000$ dalam taraf tabel signifikansi 5\%. Pada nilai Sig. (2-tailed) sebesar 0,002 yang berarti $<0,05$ sehingga dapat disimpulkan bahwa $\mathrm{H}_{\mathrm{a}}$ diterima dan $\mathrm{H}_{\mathrm{o}}$ ditolak; (2) pada kelas kontrol diperoleh skor rata-rata nilai N-Gain sebesar 0,45 dan skor pada kelas eksperimen sebesar 0,64, di mana hasil dari kelas eksperimen lebih tinggi bila dibandingkan dengan hasil kelas kontrol.

Selain itu, terdapat hasil penelitian Dewi (2017: 792) yang menyatakan model pembelajaran kooperatif tipe Two Stay Two Stray berpengaruh terhadap 
keterampilan menulis petunjuk siswa kelas III SDN di Kecamatan Karag Pilang. Hal tersebut dapat dilihat dari hasil penghitungan uji hipotesis dengan perolehan nilai thitung sebesar -6,6 atau lebih besar dari nilai tabel pada taraf signifikansi 5\%. Oleh karena itu dapat dinyatakan $\mathrm{H}_{\mathrm{a}}$ diterima dan $\mathrm{H}_{\mathrm{o}}$ ditolak.

Nilai rata-rata pretest kelas kontrol sebesar 74,01. Sedangkan pada kelas eksperimen nilai rata-ratanya sebesar 74,29. Untuk hasil posttest, kelas kontrol memperoleh rata-rata sebesar 77,76. Sedangkan pada kelas eksperimen sebesar 81,9. Ini menunjukkan perbedaan hasil pretest antara kelas kontrol dan eksperimen yang tidak terlampau jauh. Sedangkan, pada hasil posttest perbedaan rata-rata kelas kontrol dan eksperimen berbeda jauh. Hal tersebut terjadi karena adanya perlakuan berupa penggunaan model pembelajaran kooperatif tipe Two Stay Two Stray di kelas eksperimen. Perlakuan ini membuat pengetahuan siswa tentang menulis petunjuk lebih luas jika dibandingkan dengan kelas kontrol.

Pada penelitian ini akan menggunakan model pembelajaran kooperatif Two Stay Two Stray dan pengaruhnya terhadap hasil belajar siswa yang meliputi tiga aspek yang akan diteliti, yaitu ranah sikap, pengetahuan, dan keteramilan. Ketiga aspek tersebut akan diteliti pada materi pembelajaran Tematik kelas $\mathrm{V}$ tema 6 (Panas dan Perpindahannya), subtema 3 (Pengaruh Kalor terhadap Kehidupan) pembelajaran 1 dengan pemetaan muatan mata pelajaran Bahasa Indonesia dan IPA.

Perbedaan penelitian ini dengan penelitian sebelumnya yaitu pada titik fokus penelitian yang dilakukan pada jenjang sekolah dasar yang mengacu pada pembelajaran Tematik dalam kurikulum 2013. Penelitian ini difokuskan pada pengaruh model pembelajaran kooperatif Two Stay Two Stray terhadap hasil belajar pada pembelajaran Tematik di kelas V SDN Gugus XIX Kota Bengkulu.

Berdasarkan uraian di atas, peneliti tertarik untuk melakukan penelitian dengan judul "Pengaruh Model Pembelajaran Kooperatif Tipe Two Stay Two Stray Terhadap Hasil Belajar Siswa Pada Pembelajaran Tematik di Kelas V SDN Gugus XIX Kota Bengkulu".

\section{Metode}

Jenis penelitian ini adalah penelitian kuantitatif dengan metode quasy exsperiment (eksperimen semu). Menurut Sugiyono (2012: 116) metode penelitian eksperimen semu terdiri dari kelompok atau kelas kontrol, tetapi tidak berfungsi sepenuhnya dalam mengawasi variable luar yang dapat memengaruhi proses pelaksanaan penelitian eksperimen semu ini. Pada penelitian ini, kelompok atau kelas kontrol yaitu dalam proses pembelajaran kelas yang tidak diberikan perlakuan atau kelas yang tidak menggunakan model pembelajaran. Sedangkan kelas eksperimen yaitu dalam proses pembelajaran kelas yang diberikan perlakuan berupa penggunaan model pembelajaran kooperatif tipe Two Stay Two Stray.

Desain yang digunakan adalah the matching only pretest-posttest group design. Desain ini memerlukan dua kelompok sampel yang dipilih secara acak atau pengundian untuk memperoleh kelas eksperimen dan kontrol, serta diberikan tes sebanyak 2 kali, yakni pretest dan posttest. Dengan adanya perlakukan yang berbeda di dua kelas, maka terlihat perbedaan hasil belajar siswa.

Populasi penelitian adalah keseluruhan obyek yang akan diteliti oleh peneliti. Menurut Siregar (2017: 56) populasi penelitian merupakan keseluruhan dari obyek-obyek penelitian yang dapat di dalam suatu wilayah tersebut. Adapun populasi pada penelitian ini yaitu seluruh kelas V SDN Gugus XIX Kota Bengkulu yaitu terdiri dari SDN 69, SDN 89, SDN 71, SDN 72, SDN 88, dan SDN 103 Kota 
Bengkulu. Adapun karakteristik dari populasi ini yaitu tingkat pengetahuan yang tidak jauh berbeda atau setara, menggunakan kurikulum 2013, dan memiliki akreditasi A.

Menurut Sugiyono (2012: 120) sampel merupakan bagian dari populasi tersebut yang mempunyai jumlah dan ciri khas tertentu. Populasi pada penelitian ini sangat luas dan bersifat heterogen maka teknik mengambilan sampel menggunakan teknik cluster random sampling. Hal ini senada dengan pendapat Winarni (2018: 50) bahwa teknik cluster random sampling digunakan jika ditemukan populasi yang heterogen karena anggota-anggota dalam populasi suatu kelompok (cluster) terdiri dari berbagai latar belakang yang berbeda-beda seperti suku, ras, budaya, dan lain-lain.

Sampel diambil secara acak dan dilakukan dengan mengundi SDN dari seluruh populasi. Dari proses pengundian diperoleh SDN 71 Kota Bengkulu sebagai SDN eksperimen dan SDN 103 Kota Bengkulu sebagai SDN kontrol. Setelah didapatkan SDN, kemudian dilakukan pengundian lagi untuk mengambil kelas eksperimen dan kelas kontrol. Hasil pengundian tersebut didapatkan kelas V C SDN 71 Kota Bengkulu dan dengan jumlah siswa 34 orang sebagai kelas eksperimen dan kelas V SDN 103 Kota Bengkulu dengan jumlah siswa 31 orang sebagai kelas kontrol.

\section{Hasil}

Hasil penelitian diperoleh melalui proses pembelajaran Tematik tema 6 (Panas dan Perpindahannya), subtema 3 (Pengaruh Kalor Terhadap Kehidupan), Pembelajaran 1 dengan muatan mata pelajaran Bahasa Indonesia dan IPA. Dari hasil penelitian dan analisis data, nilai rata-rata pretest yang diperoleh pada kelas eksperimen untuk muatan mata pelajaran Bahasa Indonesia sebesar 48,691. Sedangkan pada kelas kontrol untuk muatan mata pelajaran Bahasa Indonesia sebesar 45,210. Nilai rata-rata pretest yang diperoleh pada kelas eksperimen untuk muatan mata pelajaran IPA sebesar 40,662. Sedangkan pada kelas kontrol sebesar 35,984. Dilihat dari nilai rata-rata hasil yang diperoleh siswa pada kelas eksperimen dan kontrol muatan mata pelajaran Bahasa Indonesia dan IPA tidak ada perbedaan yang signifikan pada nilai rata-rata pretest.

Hasil perhitungan diperoleh nilai $X^{2}$ hitung kelas eksperimen untuk muatan mata pelajaran Bahasa Indonesia sebesar 7,565 lebih kecil dari $\mathrm{X}^{2}$ tabel pada taraf signifikan 5\% sebesar 11,071. Sedanglan nilai $X^{2}$ hitung kelas kontrolnya sebesar 10,415 lebih kecil dari $\mathrm{X}^{2}$ tabel pada taraf signifikan 5\% sebesar 11,071. Hal ini menunjukkan bahwa kelas eksperimen dan kontrol pada mata pelajaran Bahasa Indonesia berdistribusi normal.

Pada muatan mata pelajaran IPA hasil perhitungan diperoleh nilai $\mathrm{X}^{2}$ hitung kelas eksperimen sebesar 9,627 lebih kecil dari $\mathrm{X}^{2}$ tabel pada taraf signifikan $5 \%$ sebesar 11,071. Sedangkan nilai $X^{2}$ hitung kelas kontrolnya sebesar 9,659 lebih kecil dari $\mathrm{X}^{2}$ tabel pada taraf signifikan $5 \%$ sebesar 11,071. Hal ini menunjukkan bahwa kelas eksperimen dan kontrol pada muatan mata pelajaran IPA berdistribusi normal.

Setelah melakukan uji normalitas dari kedua sampel, selanjutnya dilakukan uji homogenitas dengan menggunakan uji F. Sampel dikatakan memiliki varian yang homogen apabila $\mathrm{F}_{\text {hitung }}$ lebih kecil dari $\mathrm{F}_{\text {tabel }}$ pada taraf signifikan 5\% dengan derajat kebebasan (dk) pembilang dan derajat kebebasan (dk) penyebut.

Berdasarkan data yang diperoleh, nilai $\mathrm{F}_{\text {hitung }}$ pretest mata pelajaran Bahasa Indonesia sebesar 1,053 lebih kecil daripada nilai $\mathrm{F}_{\text {tabel }}$ pada taraf signifikan $5 \%$ 
sebesar 1,823 . Ssedangkan nilai $\mathrm{F}_{\text {hitung }}$ pretest muatan mata pelajaran IPA sebesar 1,373 lebih kecil daripada nilai $\mathrm{F}_{\text {tabel }}$ pada taraf signifikan 5\% sebesar 1,823. Artinya pretest muatan mata pelajaran Bahasa Indonesia dan IPA pada kelas eksperimen dan kelas kontrol berasal dari varian yang homogen.

Selanjutnya, pengujian hipotesis penelitian yang dilakukan dengan menggunakan uji-t. Apabila thitung $<t_{\text {tabel }}$ berarti tidak terdapat perbedaan rata-rata hasil belajar pada aspek pengetahuan siswa berupa pretest antara kelas eksperimen dan kontrol. Jika thitung $>$ ttabel berarti terdapat pengaruh rata-rata hasil belajar pada aspek pengetahuan siswa berupa pretest antara kelas eksperimen dan kelas kontrol.

Berdasarkan hasil perhitungan, nilai thitung pada pretest muatan mata pelajaran Bahasa Indonesia adalah 1,196 lebih kecil dari tabel pada taraf signifikan $5 \%$ sebesar 1,669 . Sedangkan pada muatan mata pelajaran IPA nilai thitung adalah 1,572 lebih kecil dari tabel pada taraf signifikan 5\% sebesar 1,669. Untuk thitung pretest kedua mata pelajaran Bahasa Indonesia dan IPA berada di daerah penolakan $\mathrm{H}_{\mathrm{a}}$. Artinya tidak terdapat pengaruh model pembelajaran kooperatif tipe Two Stay Two Stray pada kemampuan awal siswa di kelas eksperimen dan kelas kontrol atau kemampuan awal kedua sampel sama. Hal tersebut dapat memenuhi kriteria desain penelitian The Matching Only Pretest Posttes Control Group Desain karena kemampuan awalnya sama.

Adapun hasil perhitungan dan analisis data lembar posttest, nilai rata-rata posttest yang diperoleh pada kelas eksperimen untuk muatan mata pelajaran Bahasa Indonesia sebesar 73,765 sedangkan pada kelas kontrolnya sebesar 62,016. Perbedaan nilai rata-rata pada muatan mata pelajaran Bahasa Indonesia antara kelas eksperimen dan kontrol sebesar 11,749.

Pada nilai rata-rata posttest yang diperoleh pada kelas eksperimen untuk muatan mata pelajaran IPA sebesar 72,544 sedangkan kelas kontrolnya sebesar 62,661 . Perbedaan nilai rata-rata pada muatan mata pelajaran IPA antara kelas eksperimen dan kontrol sebesar 9,883. Oleh sebab itu, pada pelaksanaan posttest nilai rata-rata yang diperoleh siswa pada kelas eksperimen dan kontrol muatan mata pelajaran Bahasa Indonesia dan IPA terdapat perbedaan yang signifikan.

Hasil perhitungan diperoleh, nilai $\mathrm{X}^{2}$ hitung kelas eksperimen untuk muatan mata pelajaran Bahasa Indonesia sebesar 9,857 lebih kecil dari $X^{2}$ tabel pada taraf signifikan 5\% sebesar 11,071. Sedangkan nilai $\mathrm{X}^{2}$ hitung kelas kontrol untuk muatan mata pelajaran Bahasa Indonesia sebesar 9,204 lebih kecil dari $\mathrm{X}^{2}$ tabel pada taraf signifikan 5\% sebesar 11,071. Hal ini menunjukkan bahwa kelas eksperimen dan kontrol pada mata pelajaran Bahasa Indonesia berdistribusi normal.

Nilai $\mathrm{X}^{2}$ hitung kelas eksperimen untuk muatan mata pelajaran IPA sebesar 9,328 lebih kecil dari $X^{2}$ tabel pada taraf signifikan 5\% sebesar 11,071. Sedangkan nilai $\mathrm{X}^{2}$ hitung kelas kontrol untuk muatan mata pelajaran IPA sebesar 5,277 lebih kecil dari $\mathrm{X}^{2}$ tabel pada taraf signifikan $5 \%$ sebesar 11,071 . Hal ini menunjukkan bahwa kelas eksperimen dan kontrol pada mata pelajaran IPA berdistribusi normal.

Setelah melakukan uji normalitas dari kedua sampel, tahap berikutnya melakukan uji homogenitas dengan menggunakan uji F. Sampel dikatakan memiliki varian yang homogen apabila $\mathrm{F}_{\text {hitung }}$ lebih kecil dari $\mathrm{F}_{\text {tabel }}$ pada taraf signifikan $5 \%$ dengan derajat kebebasan ( $\mathrm{dk}$ ) pembilang dan derajat kebebasan (dk) penyebut.

Berdasarkan data yang diperoleh, nilai $\mathrm{F}_{\text {hitung }}$ posttest mata pelajaran Bahasa Indonesia sebesar 1,215 lebih kecil daripada nilai $\mathrm{F}_{\text {tabel }}$ pada taraf signifikan 5\% sebesar 1,823. Sedangkan nilai $\mathrm{F}_{\text {hitung }}$ posttest mata pelajaran IPA sebesar 1,479 lebih kecil daripada nilai $\mathrm{F}_{\text {tabel }}$ pada taraf signifikan 5\% sebesar 1,823. Artinya posttest 
muatan mata pelajaran Bahasa Indonesida dan IPA kelas eksperimen dan kelas kontrol berasal dari varian yang homogen.

Selanjutnya, pengujian hipotesis penelitian yang dilakukan dengan menggunakan uji-t. Pada penelitian ini, uji-t dilakukan untuk menguji pengaruh model pembelajaran kooperatif tipe Two Stay Two Stray terhadap hasil belajar siswa aspek pengetahuan. Apabila thitung $<t_{\text {tabel }}$ berarti tidak terdapat perbedaan rata-rata hasil belajar pada aspek pengetahuan siswa berupa posttest antara kelas eksperimen dan kontrol. Jika thitung $>$ ttabel berarti terdapat pengaruh rata-rata hasil belajar pada aspek pengetahuan siswa berupa posttest antara kelas eksperimen dan kelas kontrol.

Berdasarkan hasil perhitungan, nilai thitung pada posttest muatan mata pelajaran Bahasa Indonesia adalah 4,012 lebih besar dari ttabel pada taraf signifikan $5 \%$ sebesar 1,669. Pada posttest muatan mata pelajaran IPA nilai thitung adalah 2,941 lebih besar dari ttabel pada taraf signifikan 5\% sebesar 1,669. Maka, thitung posttest kedua mata pelajaran Bahasa Indonesia dan IPA berada di daerah penerimaan $\mathrm{H}_{\mathrm{a}}$.

Sehingga, dapat dikatakan bahwa terdapat pengaruh model pembelajaran kooperatif tipe Two Stay Two Stray terhadap hasil belajar siswa aspek pengetahuan pada pembelajaran Tematik di kelas V SDN Gugus XIX Kota Bengkulu. Hal ini disebabkan adanya perbedaan perlakuan antara kelas ekperimen yang menggunakan model pembelajaran kooperatif tipe Two Stay Two Stray, sedangkan pada kelas kontrol yang tidak menggunakan model pembelajaran.

Hasil pengamatan sikap pembelajaran Tematik yang menggunakan model pembelajaran kooperatif tipe Two Stay Two Stray untuk kelas eksperimen pada sikap percaya diri ada 1 siswa (3\%) yang berada pada kategori kurang, 6 siswa (18\%) yang berada pada kategori cukup, 12 siswa (35\%) yang berada pada kategori baik, dan 15 siswa (44\%) yang berada pada kategori sangat baik.

Pada sikap kerja sama, terdapat 1 siswa (3\%) yang berada pada kategori kurang, 6 siswa (18\%) yang berada pada kategori cukup, 13 siswa (38\%) yang berada pada kategori baik, 14 siswa (41\%) yang berada pada kategori sangat baik. Pada sikap teliti, terdapat 4 siswa (12\%) yang berada pada kategori kurang, 6 siswa (18\%) yang berada pada kategori cukup, 9 siswa (26\%) yang berada pada kategori baik, 15 siswa (44\%) yang berada pada kategori sangat baik dengan jumlah siswa sebanyak 34 orang.

Adapun hasil pengamatan sikap pembelajaran Tematik yang tidak menggunakan model pembelajaran untuk kelas kontrol pada sikap percaya diri ada 4 siswa (13\%) yang berada pada kategori kurang, 12 siswa (39\%) yang berada pada kategori cukup, 11 siswa (35\%) yang berada pada kategori baik, dan 4 siswa (13\%) yang berada pada kategori sangat baik.

Pada sikap kerja sama, terdapat 5 siswa (16\%) yang berada pada kategori kurang, 12 siswa (39\%) yang berada pada kategori cukup, 11 siswa (35\%) yang berada pada kategori baik, 3 siswa (10\%) yang berada pada kategori sangat baik. Pada sikap teliti, terdapat 7 siswa (22\%) yang berada pada kategori kurang, 9 siswa (30\%) yang berada pada kategori cukup, 10 siswa (32\%) yang berada pada kategori baik, 5 siswa (16\%) yang berada pada kategori sangat baik dengan jumlah siswa sebanyak 34 orang.

Adapun hasil pengamatan aspek keterampilan pembelajaran Tematik yang menggunakan model pembelajaran untuk kelas eksperimen pada indikator menyajikan hasil diskusi membuat diagram mengenai pokok pikiran yang terdapat pada teks bacaan penjelasan (eksplanasi) dari media elektronik secara lisan ada 1 siswa (3\%) yang berada pada kategori kurang, 4 siswa (12\%) yang berada pada 
kategori cukup, 15 siswa (44\%) yang berada pada kategori baik, dan 14 siswa (41\%) yang berada pada kategori sangat baik.

Pada indikator melaporkan hasil pengamatan mengenai bahan-bahan yang termasuk konduktor dan bahan-bahan yang termasuk isolator, terdapat 1 siswa (3\%) yang berada pada kategori kurang, 6 siswa (18\%) yang berada pada kategori cukup, 14 siswa (41\%) yang berada pada kategori baik, 13 siswa (38\%) yang berada pada kategori sangat baik dengan jumlah siswa sebanyak 31 orang.

Adapun hasil pengamatan aspek keterampilan pembelajaran Tematik yang tidak menggunakan model pembelajaran untuk kelas kontrol pada indikator menyajikan hasil diskusi membuat diagram mengenai pokok pikiran yang terdapat pada teks bacaan penjelasan (eksplanasi) dari media elektronik secara lisan ada 5 siswa (16\%) yang berada pada kategori kurang, 10 siswa (32\%) yang berada pada kategori cukup, 12 siswa (39\%) yang berada pada kategori baik, dan 4 siswa (13\%) yang berada pada kategori sangat baik.

Pada indikator melaporkan hasil pengamatan mengenai bahan-bahan yang termasuk konduktor dan bahan-bahan yang termasuk isolator, terdapat 6 siswa (19\%) yang berada pada kategori kurang, 12 siswa (39\%) yang berada pada kategori cukup, 9 siswa (29\%) yang berada pada kategori baik, 4 siswa (13\%) yang berada pada kategori sangat baik dengan jumlah siswa sebanyak 31 orang.

\section{Pembahasan}

Berdasarkan deskripsi dan hasil analisis data penelitian, hasil pretest menunjukkan tidak ada perbedaan yang signifikan pada kemampuan awal siswa antara kelas eksperimen dan kelas kontrol. Sedangkan untuk hasil analisis posttest menunjukkan terdapat perbedaan yang signifikan antara kelas eksperimen dan kelas kontrol. Perbedaan tersebut disebabkan oleh adanya pemberian perlakuan berupa penggunaan model pembelajaran kooperatif tipe Two Stay Two Stray pada kelas eksperimen dan kelas kontrol yang tidak menggunakan model pembelajaran.

Perbedaan tersebut menunjukkan bahwa model pembelajaran kooperatif tipe Two Stay Two Stray berpengaruh terhadap hasil belajar siswa pada pembelajaran Tematik di kelas V SDN Gugus XIX Kota Bengkulu. Hal ini dapat ditunjukkan dari hasil uji perbedaan pretest dan posttest yang menunjukkan hasil posttest lebih tinggi dibandingkan dengan hasil pretest.

Penggunaan model pembelajaran kooperatif tipe Two Stay Two Stray membuat siswa menjadi aktif dalam proses pembelajaran dengan kegiatan diskusi, mencari jawaban, menyimak materi yang tidak dibahas oleh kelompoknya maupun berbagi informasi sesama teman sekelas, sehingga pembelajaran tersebut berpusat kepada siswa. Hal ini dipertegas oleh Fathurrohman (2015: 91) menjelaskan bahwa kelebihan model pembelajaran kooperatif tipe Two Stay Two Stray adalah model ini siswa tidak hanya berinteraksi dan bekerja sama dengan anggota kelompoknya, tetapi siswa berinteraksi dan bekerja sama dengan kelompok lain yang memungkinkan terciptanya keakraban sesama teman dalam suatu kelas, sehingga proses pembelajaran lebih berorientasi pada keaktifan siswa dan mendorong siswa satu sama lain untuk saling berprestasi.

Setelah proses pembelajaran berlangsung, maka masing-masing kelas diberikan lembar tes berupa posttest. Posttest tersebut digunakan untuk mengetahui kemampuan siswa pada kelas sampel yaitu kelas eksperimen dan kelas kontrol. Hasil posttest menunjukkan nilai rata-rata pada muatan mata pelajaran Bahasa Indonesia di kelas eksperimen sebesar 73,765. Sedangkan nilai rata-rata pada muatan mata pelajaran Bahasa Indonesia di kelas kontrol sebesar 62,016. Untuk 
nilai rata-rata pada muatan mata pelajaran IPA di kelas eksperimen sebesar 72,544. Sedangkan pada nilai rata-rata pada muatan mata pelajaran IPA di kelas kontrol sebesar 62,661 . Terdapat peningkatan nilai rata-rata dari pretest ke posttest.

Dengan demikian, dapat dikatakan bahwa model pembelajaran kooperatif tipe Two Stay Two Stray berpengaruh terhadap hasil belajar aspek pengetahuan siswa pada pembelajaran Tematik di Kelas V SDN Gugus XIX Kota Bengkulu. Hal ini sejalan dengan beberapa hasil penelitian Fitrianingrum (2018: 953) yang menyatakan bahwa model pembelajaran kooperatif tipe Two Stay Two Stray dapat meningkatkan hasil belajar IPA kelas IV SDN Gugus 01 Sidoarjo, hasil penelitian Wijana dkk (2014: 9) yang menyatakan bahwa terdapat pengaruh yang signifikan pada hasil belajar IPA dan IPS siswa kelas V SD di Desa Kaliasem, dan hasil penelitian Arlinda (2017: 561) yang menyatakan bahwa melalui model pembelajaran kooperatif tipe Two Stay Two Stray dapat meningkatkan hasil belajar siswa kelas IV SDN 21 Sitorajo Kecamatan Kuantan Tengah.

Penggunaan model pembelajaran kooperatif tipe Two Stay Two Stray membuat siswa menjadi aktif dan terlibat langsung dalam proses pembelajaran. hal ini dapat dilihat dari siswa lebih percaya diri dalam mengemukakan pendapatnya dengan berbagi informasi kepada anggota kelompok lain, kerja sama dalam menyelesaikan tugas kelompok, serta teliti dalam melakukan pengamatan atau percobaan. Siswa aktif dalam mengerjakan tugasnya dan guru hanya sebagai fasilitator. Hal ini sesuai dengan hasil penelitian yang dilakukan oleh Kumape (2015: 361) yang menyatakan bahwa dengan menggunakan langkah-langkah yang berada pada model pembelajaran kooperatif tipe Two Stay Two Stray dapat meningkatkan keaktifan dan hasil belajar siswa tentang IPA di kelas VI SD Inpres Palupi.

Dengan menggunakan model pembelajaran kooperatif tipe Two Stay Two Stray pemahaman siswa mengenai materi yang diajarkan lebih meningkat karena siswa lebih terlibat langsung dalam mengumpulkan informasi maupun berbagi informasi kepada sesama teman, sehingga hasil belajar yang didapat lebih efektif pada individu maupun anggota kelas. Hal ini dibuktikan dengan hasil penelitian yang dilakukan oleh Herawati (2015: 104), menyatakan bahwa hasil belajar siswa mengalami peningkatan secara klasikal dan individual. Hal tersebut dikarenakan penggunaan model pembelajaran kooperatif tipe Two Stay Two Stray telah membuat siswa terlibat dalam proses pembelajaran secara aktif serta telah meningkatkan pemahaman masing-masing siswa terhadap materi yang diajarkan.

Pada hasil belajar aspek sikap terdapat perbedaan yang signifikan antara kelas eksperimen dan kontrol. Pada kelas eksperimen, aspek sikap percaya diri pada kategori baik dan sangat baik terdapat 27 orang siswa artinya siswa yang termasuk dalam kategori baik dan sangat baik sebesar 79\%. Sedangkan kelas kontrol pada kategori baik dan sangat baik terdapat 15 orang siswa artinya siswa yang termasuk dalam kategori baik dan sangat baik sebesar $48 \%$.

Selanjutnya, pada kelas eksperimen kategori baik dan sangat baik aspek sikap kerjasama terdapat 17 orang siswa artinya siswa yang termasuk dalam kategori baik dan sangat baik sebesar 79\%. Sedangkan pada kelas kontrol siswa yang berada pada kategori baik dan sangat baik terdapat 14 orang siswa artinya siswa yang termasuk dalam kategori baik dan sangat baik sebesar $45 \%$.

Kemudian, pada kelas eksperimen kategori baik dan sangat baik aspek sikap teliti terdapat 24 orang siswa artinya siswa yang termasuk dalam kategori baik dan sangat baik sebesar 70\%. Sedangkan pada kelas kontrol siswa yang berada pada kategori baik dan sangat baik terdapat 15 orang siswa artinya siswa yang termasuk dalam kategori baik dan sangat baik sebesar $48 \%$. 
Dari hasil tersebut dapat disimpulkan bahwa aspek belajar sikap kelas eksperimen dengan menggunakan model pembelajaran kooperatif tipe Two Stay Two Stray mendapatkan hasil yang lebih baik dari pada kelas kontrol, hal itu menunjukkan bahwa model pembelajaran kooperatif tipe Two Stay Two Stray dapat memberikan pengaruh yang baik terhadap hasil belajar aspek sikap siswa yang meliputi sikap percaya diri, kerjasama, dan teliti.

Hal tersebut sejalan dengan penelitian yang dilakukan oleh Kumape (2015: 359), menyatakan bahwa secara umum melalui pembelajaran yang menggunakan model pembelajaran kooperatif tipe Two Stay Two Stray siswa lebih percaya diri dalam menyelesaikan masalah yang dihadapinya dengan menggunakan pola pikirnya sendiri dan berprilaku dengan baik, serta mengorientasikan kerjasama kepada siswa dengan adanya tukar menukar informasi antar kelompok. Sehingga rasa percaya diri yang dimiliki oleh siswa berpengaruh terhadap hasil belajarnya. Selain itu, menurut hasil penelitian yang dilakukan oleh Astutik, dkk (2017: 1899) menyatakan bahwa penggunaan model pembelajaran kooperatif tipe Two Stay Two Stray dapat meningkatkan sikap kerjasama dan tanggung jawab di dalam diri siswa dan motivasi belajar timbul dengan sendirinya. Oleh sebab itu, siswa menjadi mudah untuk menyerap materi pelajaran serta mampu menyelesaikan masalah atau tugas yang guru berikan dengan baik.

Pada hasil belajar aspek keterampilan kelas eksperimen kategori baik dan sangat baik pada indikator menyajikan hasil diskusi membuat diagram mengenai pokok pikiran dan kesimpulan yang terdapat pada teks bacaan penjelasan (eksplanasi) dari media elektronik secara lisan terdapat 29 orang siswa artinya yang termasuk dalam kategori baik dan sangat baik sebesar $85 \%$. Sedangkan pada kelas kontrol pada indikator menyajikan hasil diskusi membuat diagram mengenai pokok pikiran dan kesimpulan yang terdapat pada teks bacaan penjelasan (eksplanasi) dari media elektronik secara lisan kategori baik dan sangat baik terdapat 16 orang siswa artinya siswa yang termasuk dalam kategori baik dan sangat baik sebesar $49 \%$.

Kemudian pada kelas eksperimen kategori baik dan sangat baik pada indikator melaporkan hasil pengamatan mengenai bahan-bahan yang termasuk konduktor dan bahan-bahan yang termasuk isolator terdapat 17 orang siswa artinya siswa yang termasuk dalam kategori baik dan sangat baik sebesar 79\%. Sementara untuk kelas kontrol melaporkan hasil pengamatan mengenai bahan-bahan yang termasuk konduktor dan bahan-bahan yang termasuk isolatokategori baik dan sangat baik terdapat 11 orang siswa, artinya siswa yang termasuk dalam kategori baik dan sangat baik sebesar $39 \%$.

Dari hasil tersebut dapat disimpulkan bahwa aspek keterampilan kelas eksperimen dengan menggunakan model pembelajaran kooperatif tipe Two Stay Two Stray mendapatkan hasil yang lebih baik dari pada kelas kontrol, terlihat ketika siswa aktif dalam mengikuti kegiatan pembelajaran. Hal tersebut diperkuat oleh hasil penelitian yang dilakukan oleh Hilman (2017: 150), menyatakan bahwa penggunaan model pembelajaran kooperatif tipe Two Stay Two Stray lebih baik dibandingkan metode konvensional. Itu semua terlihat dari hasil belajar dan keterampilan siswa kelas eksperimen dibandingkan dengan hasil belajar dan keterampilan siswa kelas kontrol.

\section{Simpulan}

Berdasarkan hasil penelitian dan pembahasan mengenai pengaruh penggunaan model pembelajaran kooperatif tipe Two Stay Two Stray terhadap hasil belajar siswa pada pembelajaran Tematik di kelas V SDN Gugus XIX Kota Bengkulu, didapatkan hasil uji t-hipotesis pada posttest kelas eksperimen thitung lebih besar dari tabel dengan nilai pada mata pelajaran Bahasa Indonesia thitung $(4,012)>$ 
$t_{\text {tabel }}(1,669)$, dan pada mata pelajaran IPA thitung $(2,941)>t_{\text {tabel }}(1,669)$. Sehingga dapat disimpulkan bahwa thitung lebih besar dari tabel artinya $\mathrm{H}_{\mathrm{a}}$ diterima. Sehingga dapat disimpulkan bahwa terdapat pengaruh penggunaan model pembelajaran kooperatif tipe Two Stay Two Stray terhadap hasil belajar siswa pada pembelajaran Tematik di kelas V SDN Gugus XIX Kota Bengkulu.

Hasil belajar aspek sikap kelas eksperimen dengan menggunakan model pembelajaran kooperatif tipe Two Stay Two Stray lebih baik dari pada kelas kontrol. Sikap yang diamati mencakup sikap percaya diri, kerjasama, dan teliti.

Hasil belajar aspek keterampilan kelas eksperimen dengan menggunakan model pembelajaran kooperatif tipe Two Stay Two Stray lebih baik dari pada kelas kontrol. Keterampilan yang diamati mencakup keterampilan menyajikan hasil diskusi membuat diagram mengenai pokok pikiran dan kesimpulan yang terdapat pada teks bacaan penjelasan (eksplanasi) dari media elektronik secara lisan dan melaporkan hasil pengamatan mengenai bahan-bahan yang termasuk konduktor dan bahan-bahan yang termasuk isolator dengan menggunakan model pembelajaran kooperatif tipe Two Stay Two Stray.

\section{Saran}

Berdasarkan hasil penelitian yang dilakukan, maka peneliti mengemukakan beberapa saran sebagai berikut.

1. Bagi guru

a. Sebelum proses pembelajaran dimulai, sebaiknya dalam membagi siswa kedalam kelompok guru harus mempertimbangkan kemampuan siswa terlebih dahulu agar kelompok yang terbentuk heterogen yaitu pembagian antara kemampuan anak yang tinggi, sedang, dan rendah.

b. Guru harus mengoptimalkan penggunaan waktu, karena model ini membutuhkan waktu yang cukup lama.

2. Bagi peneliti lain

Bagi peneliti lain yang ingin menindaklanjuti penelitian ini disarankan agar sehari sebelum melakukan penelitian dengan menggunakan model pembelajaran kooperatif tipe Two Stay Two Stray, siswa diberitahu terlebih dahulu mengenai langkah-langkah dalam pembelajaran seperti ada yang bertugas sebagai tamu, ada yang bertugas sebagai tuan rumah. Agar ketika hari dimana penggunaan model pembelajaran kooperatif tipe Two Stay Two Stray berlangsung, guru tidak lagi secara menyeluruh menjelaskan tugas masingmasing siswa, sehingga ini akan menghemat waktu.

\section{Referensi}

Anita, Lie, (2014), Mempraktikkan Cooperative Learning di Ruang-ruang Kelas. Jakarta: PT Grasindo.

Arlinda, (2017), Penerapan Model Pembelajaran Kooperatif Tipe Two Stay Two Stray (TSTS) Untuk Meningkatkan Hasil Belajar IPS Siswa Kelas IV B SDN 21 Sitorajo Kecamatan Kuantan Tengah. Jurnal Primary Program StuI Pendidikan Guru Sekolah Dasar Fakultas Keguruan dan Ilmu Pendidikan Universitas Riau, Vol. 6 No. 2. Hal: 555-562.

Astutik, dkk (2017 Kontribusi Metode Two Stay Two Stray Terhadap Hasil Belajar Siswa. Jurnal Inovasi Pendidikan Kimia. Vol.11 No. 01, Hal : 1893-1900.

Dewi, Kartika. Y, (2017), Pengaruh Model Pembelajaran Kooperatiif Tipe Two Stay Two Stray Terhadap Keterampilan Menulis Petunjuk Siswa SD. JPGSD, Vol. 05. No. 03. Hal: 1-9. 
Fathurrohman, M., (2015), Model-model Pembelajaran Pembelajaran Inovatif. Yogyakarta: AR-RUZZ MEDIA.

Fitrianingrum, Suci. W. (2018), Pengaruh Model Pembelajaran Two Stay Two Stray Terhadap Hasil Belajar IPA Pada Siswa Kelas IV. JPGSD. Vol.06 No. 06, Hal : 945-954.

Herawati, (2015), Penerapan Model Pembelajaran Two Stay Two Stray Untuk Meningkatkan Prestasi Belajar Siswa Pada Materi Keliling dan Luas Lingkaran Di Kelas VI SD Negeri 53 Banda Aceh. Jurnal Peluang. Vol.03 No. 02, Hal : 95-104.

Hilman, Irfan, (2017), Penerapan Model Pembelajaran Kooperatif Tipe Two Stay Two Stray pada Mata Pelajaran Ilmu Pengetahuan Sosial di Sekolah Dasar. Jurnal Pendidikan Universitas Garut. Vol.11 No. 02. Hal : 144 - 152

Kumake, Sitilin. (2015), Pengaruh Penerapan Model Pembelajaran Kooperatif Tipe Two Stay Two Stray Terhadap Aktivitas dan Hasil Belajar Siswa Tentang IPA di Kelas VI SD Inpres Palupi. Jurnal Kreatif Tadulako Online. Vol.04 No. 04, Hal : 351-362

Lestari \& Yudhanegara, (2015), Penelitian Pendidikan Matematika. Bandung: PT Refika Aditama.

Mudiofir \& Rusydiyah, (2016), Desain Pembelajaran Inovatif dari Teori ke Pratek. Jakarta: Rajawali Pers.

Shoimin, A., (2014), 68 Model-model Pembelajaran Inovatif dalamKurikulum 2013.Yogyakarta: AR-RUZZ MEDIA.

Siregar, Syofian, (2017), Statistik Parametik untuk Penelitian Kuantitatif. Jakarta: Bumi Aksara.

Sit, Masganti, (2017), Psikologi Perkembangan Anak Usia Dini. Depok: Kencana.

Sugiyono, (2012), Metode Penelitian Kombinasi (Mixed Methods). Bandung: Alfabeta CV.

Susanto, Ahmad, (2016), Teori Belajar dan Pembelajaran di Sekolah Dasar. Jakarta: Prenamedia Group.

Ula, Shoimatul. S., (2013), Revolusi Belajar. Yogyakarta: AR-RUZZ MEDIA.

Widyaningrum, Retno, (2012), Model Pembelajaran Tematik Di MI/SD. Jurnal Cendekia, Vol. 10 No. 1. Hal : 119.

Winarni, E. W, (2018), Teori dan Praktik Penelitian Kuantitatif, Kualitatif, Penelitian Tindakan Kelas (PTK), Research and Development (R\&D). Jakarta: Bumi Aksara. 